Gut, 1978, 19, 95-98

\title{
Duodenal bile acid conjugation patterns and dietary sulphur amino acids in the newborn
}

\author{
M. J. BRUETON, H. M. BERGER, G. A. BROWN, LEILA ABLITT, \\ N. IYNGKARAN, AND B. A. WHARTON \\ From the Institute of Child Health, University of Birmingham, and Sorrento Maternity Hospital, Birmingham
}

SUMMARY Patterns of glycine and taurine conjugation of bile acids in duodenal juice have been studied in 20 low birth weight babies at 12 and 22 days of age. They were fed from birth on one of three feeds containing different amounts of taurine and its precursors, cysteine and methionone. Taurine conjugation predominated in those fed on human milk throughout the first three weeks of life. In those fed on SMA or S26 infant feeding formulae, both of which contain very little taurine, concentrations of glycine conjugates were found to exceed those of taurine conjugates by the 12th day. The low glycine-taurine conjugate ratios previously described in newborn babies are, therefore, probably related to the taurine content of the milk which they received. Glycine-taurine conjugate ratios less than 1.0 occur in breast fed infants during the first three weeks of life.

At most ages, conjugation of bile acids with glycine exceeds that with taurine. In the fetus, however, and during the first week of life, taurine conjugation predominates (Encrantz and Sjövall, 1959; Poley et al., 1964; Challacombe et al., 1975). During infancy there is a gradual change to a predominance of glycine conjugation. A number of explanations for these conjugation patterns have been proposed (Jacobsen and Smith, 1968; Garbutt et al., 1971). They include reduced bacterial degradation of taurine conjugates by the less prolific intestinal flora of the newborn baby; preferential absorption of one or other conjugate; and biochemical atavism, glycine conjugation being a more recent evolutionary phenomenon (Haslewood, 1967). It has also been suggested that the limiting factor for taurine conjugation in the newborn is the availability of taurine in the liver at birth. Fetal liver is rich in taurine, and human breast milk also contains high concentrations (Ryan and Carver, 1966; Jacobsen and Smith, 1968). In adults an increase in dietary taurine enhances taurine conjugation of bile acids (Sjövall, 1959).

Although taurine is not an essential amino acid, the ability to synthesise it from cysteine and ultimately from methionine is poor in the fetus and newborn, and even in the adult the synthetic capacity of the liver is limited (Jacobsen and Smith, 1968). Methionine is normally converted to cysteine

Received for publication 4 August 1977 through the action of cystathionase and thence through cysteinesulphinic acid decarboxylase to taurine. The activity of both these enzymes is very limited in the newborn, and hence cysteine and taurine may only be available if included in the diet (Gaull et al., 1972; Sturman et al., 1977).

During a study of the effect of protein quality on growth in the newborn, we took the opportunity of observing the pattern of duodenal bile acid conjugation in babies receiving one of three different feeds. The first (human breast milk) contained the three amino acids of the transsulphuration pathway referred to above, but there was no measurable taurine present in the two infant feeding formulae.

\section{Methods}

Table 1 shows the concentration of sulphur amino acids in the food given. Expressed breast milk from Sorrento Maternity Hospital milk bank contained methionine, cysteine, and taurine. In comparison S26 ${ }^{1}$ contained no taurine, while SMA ${ }^{1}$ contained no taurine and less cysteine. The babies received one of the three feeds as their sole diet throughout the four weeks after birth. Feed quantities given were 40-60 $\mathrm{ml}$ per $\mathrm{kg}$ body weight per day, and increased to $200 \mathrm{ml} \mathrm{per} \mathrm{kg}$ by the sixth to ninth day.

Table 2 shows the weight and gestational age of the patients studied. They were all low birth weight 'John Wyeth. 
Table 1 Milk and formulae composition per litre

\begin{tabular}{lccc}
\hline $\begin{array}{l}\text { Nutrient } \\
\text { (mmal) }\end{array}$ & $S 26$ & Human milk & SMA \\
\hline Total protein (g) & 15 & 12 & 15 \\
Methionine & 2.5 & 1.5 & 2.5 \\
Cysteine & 1.0 & 1.2 & 0.4 \\
Taurine & 0 & 0.3 & 0 \\
Glycine & 1.5 & 4.5 & 1.5 \\
\hline
\end{tabular}

Table 2 Description of patients

\begin{tabular}{|c|c|c|c|}
\hline $\begin{array}{l}\text { Patients } \\
\text { investigated }\end{array}$ & $S 26$ & Human milk & $S M A$ \\
\hline \multicolumn{4}{|c|}{$\begin{array}{l}\text { Age } 12 \text { days }(n=14) \\
\text { Birth weight } \\
(\mathrm{kg})\end{array}$} \\
\hline $\begin{array}{l}\text { Mean } \\
\text { Range }\end{array}$ & $\begin{array}{l}2 \cdot 04 \\
(1 \cdot 9-2 \cdot 2)\end{array}$ & $\begin{array}{l}1.62 \\
(1 \cdot 34-1.94)\end{array}$ & $\begin{array}{l}2 \cdot 12 \\
(1 \cdot 94-2 \cdot 26)\end{array}$ \\
\hline \multicolumn{4}{|c|}{$\begin{array}{l}\text { Gestational age } \\
\text { (weeks) }\end{array}$} \\
\hline $\begin{array}{l}\text { Mean } \\
\text { Range }\end{array}$ & $\begin{array}{l}36 \\
(35-37)\end{array}$ & $\begin{array}{l}34 \\
(31-37)\end{array}$ & $\begin{array}{l}36 \\
(34-40)\end{array}$ \\
\hline \multicolumn{4}{|c|}{$\begin{array}{l}\text { Age } 22 \text { days }(n=14) \\
\text { Birth weight } \\
(\mathrm{kg})\end{array}$} \\
\hline $\begin{array}{l}\text { Mean } \\
\text { Range }\end{array}$ & $\begin{array}{l}2 \cdot 11 \\
(1 \cdot 83-2 \cdot 23)\end{array}$ & $\begin{array}{l}1 \cdot 89 \\
(1 \cdot 84-1 \cdot 94)\end{array}$ & $\begin{array}{l}2 \cdot 12 \\
(2 \cdot 02-2 \cdot 20)\end{array}$ \\
\hline \multicolumn{4}{|c|}{$\begin{array}{l}\text { Gestational age } \\
\text { (weeks) }\end{array}$} \\
\hline $\begin{array}{l}\text { Mean } \\
\text { Range }\end{array}$ & $\begin{array}{l}36 \\
(33-38)\end{array}$ & $\begin{array}{l}36 \\
(35-37)\end{array}$ & $\begin{array}{l}35 \\
(32-40)\end{array}$ \\
\hline
\end{tabular}

infants (16 male, four female), of varying gestational age. The mean gestational age of the three dietary groups was similar but the mean birth weight of the SMA and S26 groups combined $(2.08 \pm 0.12 \mathrm{~kg})$ was significantly greater $(\mathrm{P}<0.02)$ than that of the breast milk group $(1.62 \pm 0.31 \mathrm{~kg})$. The infants were already being fed by nasogastric tube, and all investigations were performed after informed parental consent had been obtained. Duodenal juice was obtained at 12 days of age in 14 babies and sampling was repeated at the age of 22 days in eight of them. Samples were obtained at 22 days from a further six infants not previously investigated.

Unweighted Vygon ${ }^{2}$ paediatric tubes were positioned in the duodenum, their siting being confirmed by changes in the $\mathrm{pH}$ and character of the juice aspirated. After a three hour fast, specimens for bile acid analysis were collected into containers on dry ice. A test feed was then given consisting of $25 \mathrm{ml}$ per $\mathrm{kg}$ of the milk on which the infant had been established. Further duodenal juice specimens were collected over 10 minute periods for the next hour. Aliquots were also placed into transport medium for bacterial culture. Total bile acid concentrations were measured using a 3-alpha hydroxysteroid dehydrogenase enzyme assay (Iwata and Yamasaki, 1964).

${ }^{2}$ Vygon U.K. Limited, Uxbridge, Middlesex.
Glycine and taurine conjugated bile acids were determined separately, by the same method, after separation by thin layer chromatography (Gregg, 1966). The conjugate concentrations were determined on the test meal specimen containing the highest total concentration of bile acid. This was almost invariably the fasting sample, the concentration being lower in subsequent samples, presumably because of dilution by the milk feed.

\section{Results}

The Figure shows the ratio of glycine to taurine conjugated bile acids. The ratio was below 1.0 on days 12 and 22 in all the babies receiving breast milk but above 1.0 in all those receiving either S26 or SMA. The mean ratios \pm one standard deviation of all the observations made on the breast fed infants was $0.62 \pm 0.21$, and on the S26 and SMA infants combined was $2 \cdot 11 \pm 1 \cdot 19$. The difference was statistically highly significant $(P<0.001)$.

The mean concentration of the glycine and taurine conjugates in the three groups is shown in Table 3. The only significant difference between the S26 and SMA groups was in the glycine conjugate levels on the 22nd day, which were higher in the $\mathbf{2} 26$ group $(P<0.05)$. Considering the SMA and S26 groups together, between days 12 and 22 there were significant rises in glycine $(P<0.02)$ and taurine conjugate levels $(P<0.05)$. There were no significant changes in conjugate concentrations in the group fed on breast milk.

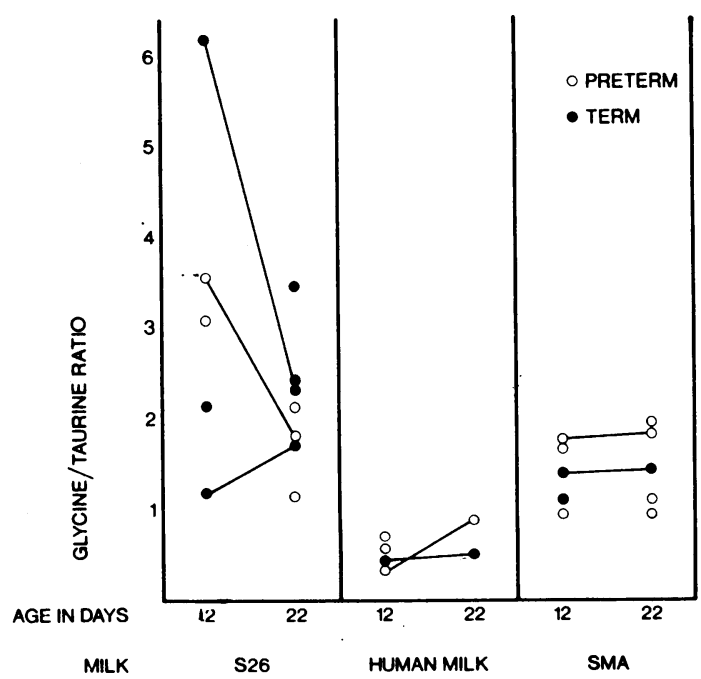

Figure Ratios of glycine: taurine conjugates of duodenal juice bile acids in relation to diet on the 12th and 22nd days of life. 
Table 3 Maximum duodenal bile acid conjugate concentrations (mmolll) observed at 12 and 22 days of age

\begin{tabular}{cccc}
\hline $\begin{array}{l}\text { Total conjugate } \\
\text { (mean +range) }\end{array}$ & $S 26$ & Human milk & SMA \\
\hline Day 12 & & & \\
Glycine & $2 \cdot 9$ & $1 \cdot 2$ & $2 \cdot 3$ \\
& $(1 \cdot 2-4 \cdot 7)$ & $(0 \cdot 3-3 \cdot 0)$ & $(1 \cdot 3-3 \cdot 3)$ \\
Taurine & $0 \cdot 9$ & $2 \cdot 0$ & $1 \cdot 7$ \\
& $(0 \cdot 4-1 \cdot 9)$ & $(0 \cdot 7-4 \cdot 8)$ & $(0 \cdot 7-3 \cdot 3)$ \\
Day 22 & $4 \cdot 6$ & $1 \cdot 4$ & $3 \cdot 2$ \\
Glycine & $(3 \cdot 0-6 \cdot 4)$ & $(1 \cdot 2-1 \cdot 6)$ & $(2 \cdot 6-3 \cdot 9)$ \\
Taurine & $2 \cdot 3$ & $2 \cdot 1$ & $2 \cdot 1$ \\
& $(1 \cdot 2-3 \cdot 5)$ & $(1 \cdot 2-3 \cdot 0)$ & $(1 \cdot 2-3 \cdot 0)$ \\
\hline
\end{tabular}

No free bile acids were demonstrated throughout the study.

Bacterial culture of the duodenal juice revealed insignificant growths of streptococci, staphylococci, klebsiella, and Escherichia coli.

\section{Discussion}

These findings demonstrate an effect of diet on the pattern of bile acid conjugation in the newborn. They show that at least by 12 days of age the newborn liver is well able to conjugate bile acids with glycine. The availability of dietary taurine does indeed appear to have an important influence on the conjugation pattern in the neonatal period. When taurine was absent from the diet, the glycine: taurine ratio had increased to values greater than 1.0 by the age of 12 days. When taurine was given, a glycine:taurine ratio below 1.0 persisted for at least three weeks. Although the glycine content of human milk was three times that of SMA or S26, the glycine conjugate concentrations found in the babies fed on human milk were much lower at 22 days. This is consistent with the concept that taurine conjugation is preferential. It is also interesting to note that taurine conjugation was no higher in the S26 group than in the SMA group despite their higher intake of cysteine, a precursor of taurine. These findings are compatible with the very limited conversion of methionine via cysteine to taurine which occurs in the newborn infant's liver (Sturman et al., 1977). Cysteine and taurine may, therefore, be essential amino acids for a short period after birth. These observations may have relevance to other areas of metabolism, as taurine is distributed widely throughout the body. Little information is as yet available on its other metabolic functions but recent investigations increasingly suggest its involvement in brain development and retinal integrity (Sturman et al., 1977).

The lower mean birth weight of the babies fed on human milk is probably not an important factor influencing taurine conjugation. Their gestational ages and their chronological ages at the time of investigation were comparable with those of the infants fed on SMA or S26. In vitro studies of the transsulphuration pathway enzymes, in fetal and neonatal liver, suggest that the major determinant of their activity is the postnatal age rather than the weight of the infant (Gaull et al., 1972). The amount of milk or formula given was calculated according to the weight of the infant concerned. Thus the heavier patients had received a slightly greater total volume of milk at the time of the study. We do not think that this, of itself, would affect the bile acid conjugation patterns, although it cannot be excluded. The frequency of the feeds given to all the babies was comparable.

Signer et al. (1974) and Norman et al. (1972) observed that duodenal bile acid concentrations in the newborn are low, often falling below the optimal micellar concentration of $4 \mathrm{mmol} / \mathrm{l}$ suggested by Badley et al. (1969). Our findings confirm this, and also showed that there was a tendency for the concentrations to increase during the early weeks of life in those fed on SMA or S26. This was statistically significant in the case of glycine conjugates.

The physiological and clinical significance of these observations in relation to fat absorption in the newborn is not known. It is well recognised that fat absorption in the neonate varies considerably according to the milk given (Davidson and Bauer, 1960). This has been related to the type of fatty acid and triglyceride ingested (Fomon, 1974). The more saturated long chain fatty acid of cows' milk butterfat is less well absorbed than breast milk fat, which, for example, contains a higher percentage of unsaturated fatty acids. The importance of differences in bile acid conjugation patterns in relation to this has not been investigated. Variation in differential conjugate absorption in the neonatal gut is another factor which may influence bile acid metabolism and fat absorption. In adults it has been shown that glycine conjugates, which have a higher pk value than taurine conjugates, may be unionised in the conditions of the upper jejunum, and then be reabsorbed in significant amounts at sites in the intestine which do not possess an active transport system for bile acids (Hislop et al., 1967). Taurine conjugates remain ionised and are absorbed in the terminal ileum. The relevance of dietary intake, and neonatal gut function to fat absorption, and patterns of bile acid conjugation clearly merits further study.

We are indebted to the staff of the Special Care Baby Unit, Sorrento Maternity Hospital, Birmingham, for their expert nursing skill, to Professor Charlotte Anderson for her support, and to Mrs Peggy Cox for secretarial assistance. 


\section{References}

Badley, B. W. D., Murphy, G. M., and Bouchier, I. A. D. (1969). Intraluminal bile-salt deficiency in the pathogenesis of steatorrhoea. Lancet, 2, 400-402.

Challacombe, D. N., Edkins, S., and Brown, G. A. (1975). Duodenal bile acids in infancy. Archives of Disease in Childhood, 50, 837-843.

Davidson, M., and Bauer, C. H. (1960). Patterns of fat excretion in feces of premature infants fed various preparations of milk. Pediatrics, 25, 375-384.

Encrantz, J. C., and Sjövall, J. (1959). On the bile acids in duodenal contents of infants and children. Clinica Chimica Acta, 4, 793-799.

Fomon, S. J. (1974). Infant Nutrition, p. 161. Saunders: Philadelphia.

Garbutt, J. T., Lack, L., and Tyor, M. P. (1971). Physiological basis of alterations in the relative conjugation of bile acids with glycine and taurine. American Journal of Clinical Nutrition, 24, 218-228.

Gaull, G., Sturman, J. A., and Räihä, N. C. R. (1972). Development of mammalian sulfur metabolism: absence of cystathionase in human fetal tissues. Pediatric Research, 6, 538-547.

Gregg, J. A. (1966). New solvent systems for thin-layer chromatography of bile acids. Journal of Lipid Research, 7, 579-581.

Haslewood, G. A. D. (1967). Bile salt evolution. Journal of
Lipid Research, 8, 535-550.

Hislop, I. G., Hofmann, A. F., and Schoenfield, L. J. (1967). Determinants of the rate and site of bile acid absorption in man. (Abstract.) Journal of Clinical Investigation, 46, 10701071.

Iwata, T., and Yamasaki, K. (1964). Enzymatic determination and thin-layer chromatography of bile acids in blood. Journal of Biochemistry, 56, 424-431.

Jacobsen, J. G., and Smith, L. H., Jr (1968). Biochemistry and physiology of taurine and taurine derivatives. Physiological Reviews, 48, 424-511.

Norman, A., Strandvik, B., and Ojamäe, Ö. (1972). Bile acids and pancreatic enzymes during absorption in the newborn. Acta Paediatrica Scandinavica, 61, 571-576.

Poley, J. R., Dower, J. C., Owen, C. A., Jr, and Stickler, G. B. (1964). Bile acids in infants and children. Journal of Laboratory and Clinical Medicine, 63, 838-846.

Ryan, W. L., and Carver, M. J. (1966). Free amino acids of human foetal and adult liver. Nature, 212, 292-293.

Signer, E., Murphy, G. M., Edkins, S., and Anderson, C. M. (1974). Role of bile salts in fat malabsorption of premature infants. Archives of Disease in Childhood, 49, 174-180.

Sjövall, J. (1959). Dietary glycine and taurine on bile acid conjugation in man. Proceedings of the Society for Experimental Biology and Medicine, 100, 676-678.

Sturman, J. A., Rassin, D. K., and Gaull, G. E. (1977). Taurine in developing rat brain: transfer of ${ }^{35} \mathrm{~S}$ taurine to pups via the milk. Pediatric Research, 11, 28-33. 